\title{
Buried Treasures: Narratives of an Immigrant from Ukraine in Israel(1)
}

\author{
Larisa Fialkova, \\ University of Haifa, Israel
}

The folklore of buried treasure is prevalent in Odessa in part because of the city's extensive catacombs and the spelunking culture that has developed around them. As Odessa's population moved across the world, its stories of buried treasure emigrated also. This paper comparatively analyzes three stories of buried treasure in Odessa and other parts of Ukraine, as recounted by an émigré to Israel. In none of them was a treasure actually found (for a discussion on stories of unfound treasures in Mexican as opposed to American folklore see Arora 1987 and Dundes 1971).

\section{The context of the fieldwork}

In the academic world, any work must be carefully designed and executed. Yet sometimes things happen by chance, without planning; or it may take years to analyze material collected with no specific aim and hardly any effort. The beginnings of this study go back to 1996, and it may be called "a typical woman's story." My electric oven broke down and I called in the electrician to fix it. He came, started working and asked if he could smoke. I brought him an ashtray shaped like Mephistopheles and jokingly asking if he wasn't afraid of it. The repairman shook his head, and said that he was used to strange and supernatural things. Hardly pausing to draw breath, he started telling stories. It was absolutely clear that Aleksandr Stanovskii was one of the best storytellers I have ever met. I told him that I was a folklorist, and asked if I could record him. So my kitchen, the so-called "woman's private space" was transformed into a place of academic activity. Not all the stories could be told at one session. A fortnight later, accompanied by my seven-year-old daughter, I visited Stanovskii at his apartment. I took her with me not by chance but after reflecting on "the self" in the fieldwork [Stoeltje et al. 1999]. Stanovskii and I were of similar age, I thought it would be better to take Lilia with me so as not to be perceived as a woman out for adventure. This time his wife was present and their daughter would go in and out of the room. Our conversation was in Russian, a native language of both of us.(2) The stories flowed in rapid 
succession with hardly any interval or change of language (Hebraisms were used twice and once Stanovskii used a Ukrainian word, bude).(3)

Altogether Stanovskii told me twenty eight stories, of which twenty four were connected with Ukraine, three with Moldova, and one with Russia. The audio recording of both interviews is stored in the Dov Noy Israeli Folktales Archives (IFA) at the University of Haifa. Some of the stories were added into the archive collection and given archive numbers (IFA 20890-20906).

At the time of the interview Aleksandr Stanovskii, a former Odessa dweller, was forty-three years old. He had immigrated to Israel in 1991 and continued working in his profession. It is important to note that his social environment was ethnically heterogeneous and consisted mainly of Russians and Ukrainians. He was raised in a secular Jewish family where Jewish dietary laws as well as other rituals were not observed. As a result, he was acquainted not with Jewish culture, but rather with local Slavic culture. For many years, Stanovskii took part in the activities of Odessa's spelunking society and was active in expeditions to Odessa's catacombs, as well as to caves in other parts of Ukraine, for example, in the Khmel'nyts'kyi and Podillia regions. He related that, in the evenings at the campsite, the weary spelunkers would sit around the fire singing songs and telling stories about the caves and their mysteries. Narrators and listeners believed them, at least partially, which is typical for legends and memorates.(4) Stanovskii's repertoire had two main themes: stories about buried treasures and ghost stories. He said that in Odessa he would tell stories among the spelunkers, but also to impress young girls. After immigrating to Israel he did not keep up spelunking and he did not have a suitable audience for his stories. Still, being an excellent storyteller he was constantly on the lookout. Any occasion could serve for telling stories, and that is exactly what happened in my kitchen.

Stanovskii took his stories very seriously. He looked for rational explanations of strange events, but these contradicted his own and other's experiences. This ambivalence influenced his manner and his storytelling alike. He told me that, in six cases, he tried to arrange experiments or to check the rumors, in four cases he approached specialists (physicians, experts in narcology, ichthyologists), and in three more cases went to the KGB or was called in there. It was very important for him to provide as many details as possible about the spatial and temporal features of the recounted events as well as the names of the people involved. Sometimes he mentioned a will of an anonymous plutocrat which allegedly had been seen by various people in the Odessa 
archives, or he mentioned information published in a book about Odessa's streets whose title he could not recall and which I failed to identify.(5) But, above all, this narrator perceived photographs as the main proof of his stories' veracity. Some pictures showed his friends who were eyewitnesses to the events he recounted. The pictures were generally of low quality, most of the eyewitnesses are now dead or mentally ill. The very fact of their tragic fate stands as proof of the credibility of their weird, if not supernatural, experiences. Stanovskii's use of low quality photographs to convince others fits into a pattern registered by folklorists studying contemporary legends in various countries [Weisman, Mendelson-Maoz 2007: 353-357; Wojcik 1996].

\section{The Tale of a Ship Made of Gold and its Versions(6)}

One of Stanovskii's tales was about a lost miniature ship of gold hidden in Odessa's catacombs. Here is his version:

Stanovskii: Folklore based on some actual facts has a tale of a ship of gold that is popular among Odessa spelunkers (podzemshchiki). Here it is. A patron of the arts of the last century exchanged all his vast assets for gold and jewelry, which for some unknown reasons he hid in the catacombs. A blessing that at that time there were lots of entrances there, a few hundred. Why is this rumor so persistent? The thing is that there were eyewitnesses who left some evidence of it, for example, there is his will in the archives which several people have seen. This is well known.

Interviewer: In what archive?

Stanovskii: In the Odessa archive.

Interviewer: In the Odessa archive?

Stanovskii: I assume so as I don't know of any other archive. The thing is that I've already mentioned that I read about it in a book, something like The Streets Tell or something of the sort, maybe Odessa's Streets, in a kind of guide book. This booklet was popular in Odessa in the fifties. I don't have it. I saw it as a bibliographic rarity in the collection of an enthusiast of Odessa's culture, an Odessa fan. The fact is that many generations of Odessa's cavers (katakombisty) would go in search of this ship and some traces of it generally. Unfortunately it has remained folklore.

Interviewer: Don't you remember the name of this person?

Stanovskii: The one who hid it?

Interviewer: The one, who hid it.

Stanovskii: Unfortunately I don't, I didn't pay attention to it. The mark was mentioned, the mark drawn where he hid it. And every single Odessa's catacomb searcher has gone through a stage of looking for it. The mark was something like an octagon which resembled a compass rose. And there was an inscription: Salve, hello.

Interviewer: Salve?

Stanovskii: Yes, salve. It's in Latin, "Hello" in Latin. And it's a brand of Odessa cigarettes (papirosy). This is a part of folklore. Anyone who visited 
Odessa's catacombs even once or twice would hear about it and be inspired by the wish to find it. That's all about that for now.

For many years I sought in vain for information on this story as well as parallels to this and Stanovskii's other stories in publications on regional folklore [see Atlas 1911; de Ribas 1995 reprint edition of 1913, Markevich 1888]. Recently, however, I have been rewarded. My luck appeared through the Internet, where I managed to find six versions of the same local legend. Legends can be found quite naturally on the Internet as this has become an important way to propagate folklore. The time when oral transmission was perceived as a principal characteristic of folk literature has passed. Now, folk texts of various genres are distributed in written form also, particularly through the Internet, fax, mobile phone, and so on. These texts reflect features of oral and written communication alike [Bar-Itzhak, Fialkova 1996; Fialkova, Yelenevskaya 2001, Rukomoinikova 2004, Weisman, Mendelson-Maoz 2007]. Absence of intonation and mimicry is partly compensated by emoticons or the graphic smiley symbols [Rozhanskii, no date], one of which is present in the text below. It is " $: \wedge$ )" meaning "embarrassment, astonishment". Often, the stories, though open to all, are directed at members of a certain group (a forum). Such is the case with the Sergei Mavrin's forum or the Odessa forum quoted below. Forum members can browse through the stories, but they often respond with their own versions. Folklore on the Internet, as in the real world, is thus part of the communicative process. The Internet does not exclude the existence of different versions, although it may reduce them through the use of a "Forward", whereby a story can be distributed without any personal intervention [Weisman, Mendelson-Maoz 2007: 350]. One could complain that the Internet is too transient; material posted there may disappear. This actually makes it even more similar to classic oral folklore.

In sum, use of the Internet complements the nature of folklore and has become the domain for a new type of fieldwork by folklorists. The versions from the Internet, all translated from the Russian original, follow here.

\section{The Ship Made of Gold, Version One.}

This was contained in the information posted by Masha on the 27 March 2005 in Sergei Mavrin's independent forum "Puteshestvie po stranam, kontinentam, gorodam $i$ vesiam" (A trip across countries, continents, cities and villages). 
Well.... In general there are many legends about the catacombs, some of them frightening, others not. I've heard a Titanic made of gold. It is said that an Odessa man of independent means who survived the Titanic disaster wanted to commemorate this event. He commissioned a gold model of the ship about $20 \mathrm{~cm}$. long. During the war he hid it somewhere in the catacombs. People would go looking for it, but they found nothing. And I've also heard about Jews who were killed there and thrown down into the mines in huge piles. Their ghosts still wander through the catacombs (http://www.s-k-mavrin.ru/phpBB2/topic102-15.html 30.10.2006)(7).

\section{The Ship Made of Gold, Version Two(8)}

This material is taken from the thematic forum Katakomby (The Catacombs), which is a part of the Odessa forum.

Deniska: Has anybody ever heard a legend about Odessa's stone pits and about the Titanic made of gold?

Clodia Tzimisce: Deniska, I haven't. What is it about?

Deniska: It's a long one; I'll try to make it shorter.

A regular millionaire and aristocrat from Odessa was among many other rich and important people who were on board the doomed Titanic. I shan't repeat that story, but I'll tell you that our guy didn't perish in the ocean. He survived although it was touch and go. Perceiving his rescue as a miracle, he asked a European goldsmith to make a gold model of that ill-fated ship for him. Odessa's narrators will never agree about the size of the ship, but all of them are convinced that it was very, very expensive. Otherwise its owner wouldn't have hidden it in one of his own stone pits in 1917. The millionaire fled from the new regime to Europe and never returned to his motherland. Many years passed. The stone pits were turned in to catacombs during the war. And the gold Titanic is still there, found by no one (http://forum.od.ua/archive/index.php/t-4646.html 30 Oct. 2006).

\section{The Ship Made of Gold, Version Three}

Catamaran-tour. Excursions and tours (Katamaran-tur. Ekskursii $i$ tury)

Sure, many legends are connected to the catacombs. Here is one of them, for example.

An Odessa magnate managed to be rescued from the ill-fated Titanic. To commemorate his miraculous salvation he ordered an exact model of the ship from the best goldsmiths. The $15 \mathrm{~cm}$. Gold Titanic made of the best quality gold was hidden in the catacombs during the Civil War. This legend was very popular in the end of the last century. Anyone who wasn't too lazy tried to find it. Yet the model of the sunken ship still hasn't been found (http://www.katamarantour.com/?p=exctours\&lang $=$ rus\&pp $=8$ 31Oct. 2006). 


\section{The Ship Made of Gold, Versions Four and Five}

\section{The "Black Sea Riviera" information center for tourists (Turistsko- informatsionnyi holding "Chernomorskaia Riviera")}

Our catacombs have their own folklore. One of these legends tells of a model of a ship made of pure gold and then hidden by an Odessa sea-captain in the catacombs. He had to go to a war and decided to hide his wealth till better times. But the seafarer never came back. And his ship hasn't been found by anyone. The second story resembles the first. It happened that a sea-captain from Odessa took part in the rescue of the Titanic's passengers. As a mark of gratitude he was given a present-a small Titanic made of gold. And this captain hid it in the catacombs before going to war. The rest you know. He never came back and his Titanic of gold hasn't been found yet by anyone. It is said that there are spelunkers who have been looking for the captain's buried treasure for a long time.

Those who go underground have a belief that you mustn't take things you find in the catacombs. According to them, everything found in the catacombs belongs to the god of rubble (Boot).(9) And if you do decide to take something you should leave something in its place. Otherwise the god of the catacombs will take revenge. Now many grown-up and reasonable people know lots of stories about the troubles that befell people who took trophies from the catacombs. The moment they returned them their life went back to normal. Interesting - what will be left in the exchange for the model of the ship of gold, if it is found? The exchange with the gods is risky because it's unpredictable. Even more when it's with the god of such a trap-like labyrinth as Odessa's catacombs (http://www.ta-odessa.com/dostop/digger/index.shtml 31 Oct. 2006).

\section{The Ship Made of Gold, Version Six}

Two versions are presented in the research article published by Pronin and Obukhov (no date). The first is identical to the Version Three above; here is the second.

"According to another version, the model was presented to a crewman of a Russian ship, who rescued a foreigner in the time of disaster. It is a known fact that among the ships that approached the Titanic was a Russian vessel Tzar (Tsar') out of Odessa. The written sources of this legend were not found. It was very popular in the 1960-1970s. Anyone who was not too lazy would go down into the catacombs under school No 56. One of the authors of this paper tried to find an element of truth in this legend... The legend about the "Gold Titanic" originated approximately in 1965. According to Leonid, a member of the "Search" (Poisk) club, an elderly man came to the militia where Leonid's brother was serving and told the story set out above. He took with him a catacomb map done on a peace of shabby cloth. It was difficult to make out anything on the map as it had been drawn by amateurs. Nobody knows what happened to the map afterwards. The militiaman told this story to his brother who was an investigator of the catacombs. Then the word of a 
gold model of a ship got out to the people round about. A secret known by more than one person is no longer a secret [Pronin, Obukhov, no date].

In sum, including the tale told by Stanovskii, we have seven versions of the same local legend and are able to build its ecotype (oicotype) [Sydow 1977; Honko 1981: 32] as shown by Aarne and Thompson [1964].

\section{A ship made of gold in Odessa's catacombs}

1. Somebody a) a patron of the arts; b) a man of independent means; c) a millionaire and aristocrat; d) a sea-captain e) other

2. Many years ago a) in the $19^{\text {th }}$ century; b) in 1917 ; c) in wartime; d) during the Civil War; e) other

3. Hid in the catacombs a) treasure; b) a gold model of Titanic; c) other

4. Which he got a) by selling all his assets for unknown reasons; b) through commissioning it to commemorate his miraculous rescue from the Titanic; c) as a gift in gratitude for his role in saving the Titanic's passengers; d) other

5. He did not take it with him because a) he fled to Europe; b) did not return from a war; c) of unspecified reasons; d) other

6. This legend was documented: a) in a will preserved in the archives; b) in a book; c) on a map drawn on a fragment of cloth; d) other 7. The treasure has still not been found.

\section{A Story of a Jewish Tomb}

The next story was partly destroyed due to problems with the recording. Regarded as corrupted, it was not accepted by the IFA. Nevertheless, to my mind it is worth publishing and relates to the stories of a buried golden ship. Stanovskii told this story as he showed me his old pictures.

Stanovskii: Here me and my friend are in the cemetery. It was an old Jewish cemetery in Odessa. Again we were looking for some legendary entrance to a legendary tomb which was connected to the catacombs. And it had to contain something like... Unfortunately we found nothing.

Interviewer: Near which tomb was it? Is there any story connected to a certain tomb?

Stanovskii: We were given a picture of a man from whose tomb there was supposed to be an entrance [to the catacombs - L.F.].

Interviewer: Do you remember his name?

Stanovskii: Unfortunately I don't anymore. 
When I had paid attention to the problem with the recording and solved it we returned to the story.

Interviewer: I hope the story about that entrance to the catacombs from the Jewish cemetery is intact on the cassette.

Stanovskii: I hope so.... I must add that we didn't destroy graves, didn't desecrate them. The only thing which we did was to lift off the tombstone, have a look inside and then put it back in place. Unfortunately that cemetery doesn't exist anymore. It was destroyed a year or two after our trips there. A park has been laid out in its place.

The theme of treasures buried in cemeteries (and not only Jewish ones) is very popular in both traditional and contemporary folklore. The newspaper Novaia Kama (New Kama) recently published information about the desecration of Elabuga's Christian cemetery, where many city magnates were buried. To stop the desecration, the staff of the city museum resorted to an old legend stating that desecrators would be punished [Kozyreva 2006].

Yet, the mentioning of a Jewish tomb is rather typical. One can imagine why these stories grew up in the Slavic context. Compared with Russian or Slavic villagers generally, who had no money and practiced mainly a barter economy, many nineteenth-century Jews were traders or craftsmen. Both of these pursuits were connected with the use of money [Bogdanov 1995: 69]. In Poland, the typical money box was a pot figure of a Jew, whose purpose was to bring financial success to its owner [Cała 1995: 163]. A personal narrative of a Belarusian villager about a tunnel connecting a Jewish cemetery to an old slaughterhouse was published by Belova [2005: 145-146].

\section{The Tutankhamen Story: IFA 20890}

While Stanovskii's narratives have an abundance of motifs from Slavic folklore, the story below makes the comparative perspective even broader, bridging contemporary personal narrative and a legend about Tutankhamen's grave.

Let's begin from far off. Let's begin with the curse of Tutankhamen's grave. You know about it, you've heard about it. There are a lot of stories, a lot of speculations and enigmas about it. Why do all of those who disturbed the peace of the grave die? And as far as I remember, those who were involved in the expedition and with the transportation - they died too and more and more and more. I've personally read five different hypotheses on this topic. The one which is quoted most often speaks about the microbes and fungus, which remained there from ancient times and causes all the damage. But this in no 
way explains numerous catastrophes, accidents etc., etc. This is an introduction (predystoriia).

And here is the story. Well, there is a lake near Chernigov. I'm racking my brains to remember its name, but I can't. It has a local name and a different official name, which is used on the maps and guidebooks. There is a small river and a lakelet. According to a well known legend, Napoleon or someone else sank his treasure-chests there. It was either at the time of an attack or at the time of a retreat. I had never heard about this lakelet. I simply joined an organized tour trip to that district, which was not so typical for me. That's how I heard about it. So there we were at this lake. It wasn't my group. We were invited by another group of tourists, hikers and water tourists (turistypeshekhodniki $i$ vodniki). Not that it matters.

One of the main attractions for the tourists was usually a hike to the nearby village, naturally to find wine and to seek adventure. So in that village I, along with my friend Kolia Timofeev, who sadly died later, and my friend Volodia Pitel', who is or rather was being treated in Odessa's mental hospital, got acquainted with an old man. All this is very significant as these circumstances have to do with the events which I'm telling you about. So we got acquainted with this old.... We bought some wine from him. And as he invited us to taste the wine before paying for it, we stayed there for a good while. I think that we "tasted" something like five-six liters of that wine.

I was younger then and was getting drunk rather slowly. This old guy was drinking on a par with us and yet remained absolutely sober, at least as far as I could tell. Well, we got onto that legend about buried or sunken treasure. He chuckled and said: "You're not the first and won't be the last to look for it". Then he added: "The treasure is certainly in the district, but not in this lake. And wasn't hidden or sunken by Napoleon. I know about these things: I am the guardian".

I don't really know whether he was serious or not, or whether he was sober or not. The old guy (dedok) was in fact strange, very nimble and agile. He would make certain barely discernable gestures. What I'm saying, as I can recollect it today, is that sometimes he didn't behave like an old man at all. To make it clear I'll try to define everything in brief.

I mentioned Pharaoh's curse because this curse, Pharaoh's curse, has only one theory that can really explain everything. The priests of ancient Egypt knew of a rather primitive hypnosis technique which is in use still today in that very same mental hospital. I pricked up my ears when this old guy (dedok) gave a clue. It's always possible to produce a child or to kidnap a child or to find a child so as to pass your own function to him/her. That is, when an old man or an old woman, the sex doesn't really matter here, feels that he/she is too old and weak and is unable to accomplish his/her function, he/she simply transfers it to the new generation. This generation gets used to the altered situation and continues to live in the same district fulfilling the same function. I can imagine fairly well that a person who disturbed the peace of Pharaoh's grave was condemned by such guardians. In the daytime they can work at a factory while at night they can execute the sentence.

Well, this old fellow (dedok) hinted at this during our long talk around the table.... He didn't say it explicitly like I am now, but just hinted. Unfortunately, the next day we quarreled with him a bit and he said: "Guys, yesterday I told you more than I should have. If you don't want to have any 
regrets, then better keep quiet". And we did keep silent. Now both of my friends are unlikely to talk about it, while I'm too far away from there to be afraid of anything. That's all on this point.

Stanovskii's story is a personal narrative (a memorate in both the narrow and broad sense of this term) which includes many popular folklore motifs, such as death as a punishment for breaking the silence about the buried treasure [Bogdanov 1995: 19]. Many books, papers and films have been produced about the curse of Tutankhamun's grave, and Stanovskii himself was acquainted with some of them. Information from written sources likewise enriched his repertoire of stories. This feature has been defined by the Russian folklorist Sergei Shtyrkov as "secondary folklorization" [Shtyrkov 1999: 27](10). The narrator explicitly mentions some of the theories that demystify the events following the discovery of the grave and its treasures, but did not perceive them as believable.

At the time of our meeting in 1996, neither Hoving's nor Nelson's research had yet been published, so Stanovskii could obviously not have been aware of these studies. According to Hoving, the legend about the curse (including all the hieroglyphics threatening intruders) was fabricated by the mass-media, which included in the list of victims any member of the expedition who had died - even many years later [Hoving 2002: 226-230]. Nelson analyzed the biographies of forty four Western foreigners who, according to the archeologist Howard Carter, were in Egypt at the time of the opening of Tutankhamun's burial chamber. Twenty-five of them were present at the opening and could have been "cursed".

Hypothesizing that the so-called "curse" was bound to be due to physical rather than metaphysical factors, Nelson meticulously examined the biographies of those who were present during at least at one of four events: the opening of the third door to the chamber on the 17 February 1923, the opening of the sarcophagus on 3 February 1926, the opening of the tomb on 10 October 1926, and the examination of the mummy on 11 November 1926. Nelson compared the longevity of all the "cursed" people with that of those who had not approached the tomb. He took into account several factors, among them their gender and age, as well as the average life term for men and women of that period. He discovered that the deaths were entirely natural, leaving no room for a curse [Nelson, 2002, 325: 1482-1484].

The second legend referred to in Stanovskii's story is about Napoleon's trophies. Napoleon, on his flight from Moscow gave orders 
to sink the trunks with the trophies in Semelin lake [Scott, 2000: 553], known in Russian as Semlevskoe ozero. This knowledge impressed many generations of people, who have been looking for this treasure for more than two centuries [Nizovskii 2001: 213-244]. Considerable material describing this ongoing quest, both in the Semelin lake and in Belarus, can be found on the Internet [Glazkov 2003; Ulanenkoff no date]. According to Nizovskii, while the Semelin version is entirely makebelieve, the Belarusian one is more credible [Nizovskii 2001: 222-227; 232]. These searches have also been reflected in Russian fiction [Bukchin 2004; Bulychev 1992]. I would also mention one more version, according to which the trunks were never buried. It holds that Napoleon divided the treasure among his solders with the obligation to return everything to him on their arrival to Paris (no author, no date http://ostmetal.info/arta2e71fff.phtml 3 Nov. 2006). I have not come across any version which connects Napoleon's treasures with Ukraine. The only thing known to me in this regard is that both Ukrainians and Russians have hunted for it on the way to Smolensk [Scott 2000: 546]. Nevertheless, Ukraine is sometimes called "a country of buried treasures" and among the most famous relevant legends is the one about hetman Mazepa's trunks [Grinchenko 1900: 179-180; Nizovskii 2001: 153, 189-196](11).

Having reviewed the legends from Stanovskii's introduction, I move on to the central episode, namely the narrator's meeting with the old man (dedok) near Chernigov. This story also has its versions, one of which I found on the Internet. It is also connected to Ukraine, although another region. Here is a story from the Internet.

An elderly "consultant" can be found in almost every village. He can describe the buried treasure and the ways of getting it in detail and in a business-like manner. One such consultant, who lives approximately sixty kilometers from Zhitomir, agreed to my request to tell about looking for treasure. Here is what old Anton (ded Anton) told me:

"Buried treasure it is no joke. Many people have perished because of this damn gold (zolotishka prokliatogo)! And here it can indeed be found. Buried treasure - not just gold and stones. From the moment it is buried, it is guarded by unseen forces. Usually the owner of the gold pronounces the oath (zarok) before hiding it. This oath has information about the person who can get the treasure and the time when he can find it. Sometimes he is said to be a 'lucky man' or the 'next man'. Yet there are cases when the treasure may be destined 'for a human's head' or even for several 'heads'. This means that to get the treasure you have to kill someone. A treasure is buried till a certain date. Nobody can get it before that date. How do you look for a treasure? Being buried, it manifests itself with smoke, fire, 'red roosters'. Where a passerby sees a glow, he must start looking for it. In the swamps, a treasure

FOLKLORICA 2007, Vol. XII 
sometimes rises up above the groundwater to dry out. But all these are old women's lies. But there are other things which are true. My grandfather told me how a clever robber (vakhlak) would bury a treasure in a highly sophisticated way. Hide it in such a way that no one would see it, and finding out about it was difficult, and the time for doing so was usually short. That's why the possessors of treasure would dig pits as if for slaughtered horses. At the bottom they would place the trophies, which they couldn't take with them. They tossed the horses' carcasses down on top of them, sometimes even human bodies. Such pits were quickly covered up and a simple cross was stuck in. Even in our day it's done in the same fashion. Stones and gold (kameshki $i$ zolotishko) were hidden in the graves. It was done during the Civil War as well as during the Great Patriotic War. Who would contemplate digging up a grave?"

"A buried treasure can be 'met with' in the daytime as well", old Anton went on seriously. "If you see a pig or a foal in the forest in daytime it means that silver is somewhere nearby. And if you manage to see a cock in the forest, keep calm: you're standing over the gold. My grandfather taught me: if you're agile and can hit this animal or this bird, you'll get a load of money. All buried treasure is guarded. There are various locks and spirits of animals and people that serve as guardians. The old people used to say that treasure was buried together with a person who had to guard it until somebody could replace him. The treasure seekers tell about stallions that neighed in the graves, about wolves that pounced on diggers and about merry Cossacks sitting on barrels full of money. The Cossack offered any passerby vodka or money. Whoever chose the money had to replace him in guarding the treasure" [Koval'chuk, no date].

Both versions of this story, the first narrated by Stanovskii and the second posted by Koval'chuk, tell of a personal meeting with an old interlocutor in a Ukrainian village and of the mysterious guardians who can transfer their mission to someone else, as well as about numerous deaths among the treasure seekers.

The motif of the grave as a treasure locus reminds us of Stanovskii's previous story about the Jewish cemetery and of the legend about Elabuga's Christian cemetery. Comparative folklore often emphasizes the link between the dead and treasure. Quite evidently, the guardians of Zhitomir's treasure are "relatives" of the dragon in Beowulf, as are the keepers of the treasure in Germany, Scotland, France, Sweden, Mexico, and, of course, Ukraine [Arora 1987: 83; Bogdanov 1995: 64; Lindow 1982: 260; Schryer 1976: 710; Skunts' 1972: 186-189; Yekelchuk 1998: 322]. Such resemblance is caused by the fact that buried treasures form a stable image in pagan mythology [Nizovskii 2001: 5]. In this sense Chernigov's and Zhitomir's treasure guardians may be deemed relatives of those who "guarded" Tutankhamun's grave - where, incidentally, small model ships were actually found. They were made of wood, not 
gold, but they were gilded. According to ancient Egyptian, beliefs these ships were to serve the dead Pharaoh in the other world [Jones 1990: 17]. A question arises: Did these models, together with the Titanic, perhaps influence the "tale of the ship of gold" that made its way into Odessa's catacombs from the world of the dead? Contemporary legends develop from traditional folk motifs, according to which money and treasure are connected 1) with the world of the dead and its representatives (devils, ghosts etc.) 2) with socially marginal people (soldiers, robbers, sailors) and 3) with ethnic and/or religious minorities such as Jews, Gypsies, and Tatars [Bogdanov 1995: 75; Nizovskii 2001: 9].

Returning to the Odessa region, I would like to stress that the information about buried treasure here is fairly widely known [see e.g. Nizovskii 2001: 157-158, 293-294] and is sometimes real: ancient coins were found in 1963 in the village of Orlovka [Bondar' and Bulatovich, 1992].(12) It is absolutely clear that such findings stimulate both treasure-seeking and the legends about it. Scholars have even created a special term - supernatural economy - to define the widespread phenomenon of treasure-seeking [Taylor 1986]. Serhy Yekelchuk even supposed that a legend about hetman Polubotok's treasure, popular in Ukraine in 1990-1991, had a real influence on the nationalist movement in that country [1998: 315]. I find his idea to be an exaggeration. This legend, as often happens in folklore, was popular in certain groups while entirely absent from others. Neither I nor my relatives and friends ever heard of it in the early 1990s.(13) But I do agree with Yekelchuk's other conclusion, namely that support of Ukrainian independence by many representatives of various strata, including those who were not nationalist at all, was inspired by unrealistic dreams of instant economic success. The same may be said about many immigrants from Ukraine who hoped that border-crossing would automatically grant them prosperity.

At the beginning of the twentieth century, de Ribas stated that old Odessa, which had been the city of folk ghosts, fears and superstition, no longer existed [1995, reprint edition of 1913: 167]. As Stanovskii's stories clearly show, he was mistaken. Stories about various supernatural events in the catacombs as well as stories about house spirits (domovoi), the Evil Eye and sometimes even witches are recorded in Ukraine as well as in Israel from immigrants from the former Soviet Union [Belova 2005; Cavaglion and Sela-Shayovitz 2005: 258-259; Fialkova and Yelenevskaya 2007: 278-283; Golovakha-Hicks 2006; Tartakovsky 2001]. I believe that all these recordings should be studied from a 
comparative perspective. This will help us to understand the relationship between Ukrainian and other folklore traditions, while also giving us the opportunity to analyze new methods of transmission and variation as people and ideas migrate across the world.

\section{NOTES}

1 Parts of this paper were previously published in Russian and in Ukrainian: «Катакомбный фольклор Украины», Живая старина, 1998, 2: 35-37; «Сучасні легенди 3 України в Ізраїлі» У зб.: Г. Аронов (ред.) Єврейська історія та культура в Україні: Матеріали конференції 2-5 вересня 1997. Київ, 1997, 213-218; «Підземна Україна в особистих оповідях». У зб.: Етнологія, Фольклористика. Четвертий Міжнародний конгрес україністів. Одеса, 1999, кн.. 1, с. 459-467. http://mau-nau.org.ua/kong/Odesa/Book1/Art55.htm

Nevertheless, this paper is original as it contains more than $30 \%$ of new material. The information about the narrator and Stanovskii's stories were published earlier while all the comparative analyses of the versions are new.

2 Stanovskii speaks a rather standard colloquial Russian and not its Odessa subtype [see Rothstein, 2001: 782-787].

3 The Stanovskiis speak Russian as well, although Aleksander's wife Oksana is an ethnic Ukrainian. In my presence Oksana communicated with their seven-year-old daughter in Hebrew.

4 The length of the paper does not allow me to discuss the problem of terminology, but I do discuss it in my forthcoming book "When Mountains Meet: Essays in Ukrainian-Israeli Comparative Folklore". In general, I prefer such terms as personal narratives and legends and I don't use the term fabulate at all. I rarely use Sydow's term memorate, introduced in 1934 [Sydow 1977a] as its meaning is understood differently by various researchers. Some colleagues perceive it as meaning any personal narrative presented as credible, while others treat it as a personal narrative about supernatural experiences. Sometimes only first-hand accounts are understood by the folklorists as eligible for this term while in other papers second- and third-hand accounts also qualify. In any case, most of Stanovskii's narratives can be called memorates: first, all of them were presented as credible, and, second, most of them tend towards mysterious accounts. A few stories were perceived by the narrator himself as legends. 
5 Of course, it may be found later. Thus I. Golovakha and O. Britsyna finally were able to find a rare book about the village of Ploske which was not registered anywhere and which they were already inclined to perceive as the fruit of folk imagination [Golovakha, 2004: 14].

6 The original name is Skazochka o zolotom korablike. In this context the word skazochka means a legend rather than a fairy tale. This story is registered in IFA, number 20900.

7 I give the date when I checked sites for the last time as materials can disappear from the Internet (of course, I print them out and preserve them in my own archives). The legend about the ghosts of the killed Jews has no parallels in Stanovskii's repertoire although it does contain ghosts' stories. This legend can be found at the same sites as the versions of the legend of the ship of gold.

8 The use of nicknames instead of real names is typical of the communication process on the web. In the original the nicknames were typed in Latin.

9 The god of rubble (Boot) is a personified building material which is extracted from the catacombs. Among spirits guarding buried treasures, Ukrainian folklore knows those such as Blood, Mara, Khovala [Nizovskii, 2001: 159-160].

10 The same phenomenon but without reference to Shtyrkov was registered by Golovakha-Hicks [2006]. The use of printed sources for oral narratives was demonstrated much earlier by Mullen on non-Slavic material [1971: 410].

11 According to Ukrainian folklore, a treasure can disappear down the drain with a treasure-seeker in it and come out again in Jerusalem [Grinchenko, 1900: 178-179].

12 Israeli archeologists recently announced the find of an old grave from the Roman period at Beit-Shean. It was a chance discovery made during the renewal of the town's sewerage. It contained a weapon, ceramics, gold and jewelry, as people were buried together with their property. The exact place of the grave is kept secret in order not to attract treasure seekers.

(http://www.mignews.com/news/travel/world/311006_105023_50519.ht ml 31 Oct. 2006).

13 At that time I was still a Kyiv dweller. I immigrated to Israel in April 1991 


\section{BIBLIOGRAPHY}

Aarne, Antti, and Thompson, Stith (1964) The Types of the Folktale: A Classification and Bibliography. Helsinki: FFC No. 3.

Arora, Shirley L. (1987) Memorate as Metaphor: Some Mexican Treasure Narratives and Their Narrators. In: Gillian Bennett, Paul Smith and J.D.A. Widdowson (eds). Perspectives on Contemporary Legend, vol. II. Sheffield: Sheffield Academic Press, 79-92.

Atlas - Атлас Д. (1911) Старая Одесса, ее друзья и недруги. Одесса, 93-108.

Bar-Itzhak, Fialkova - Бар Ицхак, Хая, Фиалкова Лариса (1996) Фольклор и компьютер: К постановке проблемы. Язык и культура. Четвертая международная конференция. Материалы. Киев, 143-152.

Belova - Белова О. (2005) Этнокультурные стереотипы в славянской народной традиции. Москва: Индрик.

Bogdanov - Богданов К. (1995) Деньги в фольклоре. СанктПетербург: РАН (Пушкинский Дом).

Bondar', Bulatovich - Бондарь Р.Д., Булатович С.А. (1992) Нумизматические памятники Нижнего Подунавья. В сб.: Историческое краеведение Одесщины. Одесса. Вып. 1, 21-23.

Bukchin - Букчин C. (2004) Клад Наполеона. Москва: МФЦП.

Bulychev - Булычев К. (1992) Клад Наполеона. В кн. К. Булычев. Приключения Алисы. В 6-ти книгах. Кн.5 Москва: Культура, 43-49 (http://www.rusf.ru/kb/stories/klad_napoleona/text01.htm 3.11.2006).

Cała, Anita (1995) The Image of the Jew in Polish Folk Culture. Jerusalem: The Magnes Press, the Hebrew University.

Cavaglion, Gabriel, and Sela-Shayovitz Revital (2005) The Cultural Construction of Contemporary Satanic Legends in Israel. Folklore 116(3): 255-271.

de Ribas - де Рибас, Александр (1995, репринтное здание 1913). Старая Одесса. Москва: Dimoff \& CO.

Dundes, Allan (1971) Folk Ideas as Units of Worldview. Journal of American Folklore, 84(331): 93-103.

Fialkova - Фіалкова, Лариса (без дати) Коли гори зустрічаються (Нариси 3 українсько-ізраїльських фольклорних взаємин). Київ: Інститут мистецтвознавства, фольклористики та етнології ім.. М.Т. Рильського (у друку).

Fialkova L., Yelenevskaya M. (2001) Ghosts in the Cyber World: Analysis of the Folklore sites on the Internet. Fabula, 1-2: 64-89. 
Fialkova, Larisa and Yelenevskaya, Maria (2007) Ex-Soviets in Israel: From Personal Narratives to a Group Portrait. Detroit: Wayne State University Press.

Glazkov - Глазков (2003) Тайна кладов Наполеона. Российская земля (Аграрная партия России), вып. 15. 18.07.

(http://www.agroparty.ru/smi/154/).

Golovakha - Головаха, Інна (2004) Село Плоске: його традиції та виконавці. У кн..: О. Бріцина, І. Головаха. Прозовий фольклор села Плоске на Чернігівщині. Київ: Інститут мистецтвознавства, фольклористики та етнології ім. М.Т. Рильського, 7-37.

Golovakha-Hicks, Inna (2006) Demonology in Contemporary Ukraine: Folklore or "Postfolklore"? Journal of Folklore Research, 43(3): 219-223.

Grinchenko - Гринченко Б.Д. (1900) Из уст народа. Чернигов.

Honko, Lauri (1981) Four Forms of Adaptation of Tradition. Studia Fennica, 26. Helsinki: 19-33.

Hoving, Thomas (2002) Tutankhamun: The Untold Story. New York: Cooper Square Press.

Jones, D. (1990) Model Boats from the Tomb of Tutankhamun. Oxford: Griffith Institute.

Koval'chuk - Ковальчук В. (без року) Клады и подземелья Житомира.. Были и легенды.

(http://cathedral.net.ua/articles preview 136 print.htm 3 Nov. 2006).

Kozyreva - Козырева Л. (2006) Легенда о Троицкой церкви. Новая Кама: Елабужская общественно-политическая газета, 31 октября (http://newkama.elabugae.ru/news full.php?id=22 2.11.2006).

Lindow, John (1982) Swedish Legends of Buried Treasure. Journal of American Folklore, 95(377): 257-279.

Markevich - Маркевич А.И. (1888) Одесса в народной поэзии. Труды VI археологического съезда в Одессе (1884). Т.2., Одесса, 398-418.

Mullen, Patrick B. (1971) The Relationship of Legend and Folk Belief. Journal of American Folklore, 84(334): 406-413.

Nelson, Marc (2002) The Mummy's Curse: Historical Cohort Study. British Medical Journal, 325: 1482-1484 (21 December).

Nizovskii - Низовский А. (2001) Зачарованные клады России. Москва: Наука.

Pronin, Obukhov - Пронин К.К., Обухов А.В. (без року). В катакомбах 56-ой школы.

(http://uzm.spb.ru/archive/56 school_catacombs.htm 31.10.2006). 
Rothstein, Robert (2001) How It Was Sung in Odessa: at the Intersection of Russian and Yiddish Folk Culture. Slavic Review, 60(4): 781-801.

Rozhanskii, no date - Рожанский Ф.И. (без року) Точка, точка, запятая (эмотиконы как живая семиотическая система). (http://www.belb.net/obmen/Rozhanski.htm 30 Oct. 2006).

Rukomoinikova - Рукомойникова Вера (2004) «Виртуальный» фольклор в контексте народной смеховой культуры: Автореферат диссертации на соискание ученой степени кандидата филологических наук. Ижевск.

Scott, W. (2000) The Life of Napoleon Buonaparte, Emperor of the French. Ann Arbor: Mich.

Schryer, Frans J. (1976) A Reinterpretation of Treasure Tales and the Image of Limited Good. Current Anthropology, 17: 708-710.

Shtyrkov - Штырков, Сергей (1999) Исторические предания и перспективы изучения традиционных нарративных практик. Мифология и повседневность, вып. 2. Материалы научной конференции 24-26 февраля 1999. Санкт-Петербург: Алитея, 25-34.

Skunts' - Скунць П.М., упор. (1972) Легенди нашого краю. Ужгород: Карпати.

Stoeltje, Beverly J., Fox Christie L. and Olbrys Stephen (1999) The Self in "Fieldwork": A Methodological Concern. Journal of American Folklore, 112(444): 158-182.

Sydow, Carl Wilhelm von (1977) Geography and Folktale Oicotypes. In C.W. von Sydow Selected Papers of Folklore. New York: Arno Press, 44-59.

Sydow, Carl Wilhelm von (1977a) The Categories of Prose Tradition. In C.W. von Sydow. Selected Papers of Folklore. New York: Arno Press, 86-88.

Tartakovsky, Eugene (2001) Group Psychodynamics of Witchcraft and Witch-hunting: Immigrant Adolelescents from the Former Soviet Union in Israel. Group Analysis, 34(1): 129-142.

Taylor, A. (1986) The Early Republic's Supernatural Economy: Treasure Seeking in the American Northeast, 1780-1830. American Quarterly, 38: 6-34.

Ulanenkoff S. Семлевский клад: вокруг да около. (http://usveter.narod.ru/semlevo.html 3 Nov. 2006).

Weisman, Limor, Mendelson-Maoz, Adaya (2007) "Please, Forward the Story": sipurim amamiim - mikikar ha-shuk el ha-merhav ha-virtuali ("Please, Forward the Story": Folktales - from a Market 
Square to the Virtual Space, in Hebrew). In: Eli Yassif (ed.) Sadan: Studies in Hebrew Literature. Studies in Jewish Folklore in a Changing World. Tel-Aviv: Tel Aviv University, 343-375.

Wojcik, D. (1996) Polaroids from Heaven: Miraculous Image Tradition at a Marian Apparition Site. Journal of American Folklore, 109(432): 129-148.

Yekelchuk, Serhy (1998) Cossack Gold: History, Myth, and the Dream of Prosperity in the Age of Post-Soviet Transition. Canadian Slavonic Papers, XL(3-4): 313-325. 